\title{
The Challenges Of Education In The Millennial Era
}

\author{
Hendrik B. Tetelepta, ${ }^{1}$ Desetina Harefa ${ }^{2}$ \\ Theology Study Program, Real Theological Seminary Batam \\ bernadustetelepta@gmail.com
}

\begin{abstract}
Human being transforms over time, from one generation to another. Each one shows and marks their characteristic at one specific era. The MILLENNIAL or MILLENNIUM era presents a generation of people who are occupied with different characteristics that make them draws a lot of attention. Generally this millennial generation is YOUNG PEOPLE who live at the average age of 17-35 years old. They are often referred to as generation $Y$, which distinguishes them from the earlier generation (generation $\mathrm{X}$ ), and there after (generation $\mathrm{Z}$ and Alpha). The $\mathrm{Y}$ are born, grow and develop in the midst of the development of science and technology, especially the information technology which is very advanced and sophisticated. This generation's lifestyle cannot be separated from the presence and impact of the information technology. Questions such as: what platform they use, how they communicate, and how they learn: are questions that occasionally discussed among educators andby various educational institutions. Information technology based products such as: E-mail, SMS, Facebook and Twitter are always used by these millennials, and so cell phones, laptops, internet, are always carried everywhere and operated in communication and learning. Through these tools, millennials communicate and access information widely and rapidly.
\end{abstract}

Keywords: Challenges, Education, Milenium Era

\section{INTRODUCTION}

Technological developments and times have led to changes in the pattern of education in today's education. Educational methods and curriculum changes are phenomena that are applied in various ways in schools. The fact is that the curriculum in Indonesia still seems too dense, it should be thought that the curriculum was formed as an effort to support alignments for learning. Often times the benchmarks used tend to be purpose-oriented in the pursuit of values, leaving little time for the deepening of interests and talents. Therefore, indeed the development of technology and human resources must go hand in hand to answer existing educational problems. Education must continue to innovate from time to time. There needs to be a comprehensive alignment for practitioners and educational institutions between educational values and technological sophistication in the fast times. Likewise, Christian education does not remain silent in facing these challenges, and adapts in the progress of today's times. 


\section{METHOD}

This research is a textual analysis based on a comparison of clasical and virtual learning that aims to evaluate the education that develop in the flow of the modern world with the most relevant christianity views so that the christian must aware for the change of civilization.

\section{RESULTS AND DISCUSSION}

The image and concept of the education in contemporary society is very much different from the concept of the past. Globalization also caused a shift in the world of education which was originally a face-to-face system began to lead to an online system. With the inclusion of globalization in the world of education resulted in interactions between people also shifted and without denying that these things will increasingly disappear.

In the era of globalization based on digital applications in the world of education. This will help the learning process and can also improve performance results. The increasing number of technology users in the world of education will lead to changes in learning models. Because it is more effective and efficient, without requiring much time and effort. So that people will gradually prefer online learning systems over conventional learning (face to face).

The development of various learning media is in line with the rapid advancement of technology. The dynamics of technology are now achieving extraordinary acceleration. Technology that has been learned several years ago has been replaced with new technology, including conventional learning.

The learning model provided in technology for education is considered quite effective. Distance learning (distance learning) between teachers and students who are not in one place or long distance relationships. And technology also provides many other learning options that can be enjoyed by the general public very easily. Now we are also experiencing the ease of learning just by accessing digital applications such as e-journals, e-libraries and so on.

One learning model that has been applied by several communities is the Elearning model. E-learning is a form of learning model that is facilitated and supported by the use of information and communication technology. The term Elearning is more precisely intended as an effort to make a transformation of the learning process in schools or colleges into digital form which is bridged by internet technology.

\footnotetext{
${ }^{1}$ Munir, Pembelajaran Jarak Jauh Berbasis Teknologi Informasi Dan Komunikasi (Bandung: Alfabeta, 2009).169
} 
In Indonesia, the conventional education system is still widely practiced within the academic community. Especially areas that are still classified as rural. Because abroad such as France has also used online education services which is evidence of a shift in the direction of the world of education. Especially now, today that demands a big change in the world of education. Where education is used as a benchmark in a society. So that the rich education has broad knowledge to transfer knowledge.

Related to the condition of Indonesia in 2045 Indonesia's population is predicted to reach 321 million people. In that period 70 percent of Indonesia's population was productive age population. ${ }^{2}$ Millennial generation population reaches $50.36 \%$ of the total productive age population. ${ }^{3}$ Milennials' ability to access various information as a result of the fast and advanced information technology development, on the one hand is an opportunity, but on the other side brings drawbacks and shows its own challenges in the life of our society, especially in the field of education. The direct perceived advantage is that students and educators find it much more easier to get information about aspects related to scientific matter in the learning process.

Learning material is not only limited on textbooks, obligatory books or required textbooks, bur also acquiredin brochures, journals, magazines, videos, newspapers and others. Students or lecturers also possible directly communicate directly to the book and journal author, journal or publisher. At the same time, students and lecturers can present their resource persons through videos that are operated in class when the learning process takes place. Another advantage is as a tool, learning process takes place. Another advantage is as a tool, learning media mus be included as one of the requirements in the learning activities and this is very important to be fulfilled, considering its role and the role of media facilitates for the achievement of learning goals.

In addition to the facilities mentioned above, there are a number of weaknesses which can be called challenges that have to be faced by the community, especially the education community. Information technology based products that are highly developed are often missused for things that are not appropriate, not only in the field of education but in other fields such as: the spread of false news/ hoaxes, slander, the spread of hate speech, defamation of certain religions, violence, ATM burglary, fraud, rape, terrorism, robbery and others. This

\footnotetext{
2 Kurniasih Budi, "Sambut Bonus Demografi, Indonesia Dorong Negara G-20 Kerja Sama," n.d., https://money.kompas.com/read/2019/06/24/205905526/sambut-bonus-demografi-indonesia-dorong-negara-g20-kerja-sama?page=all.

3 "HIPMI Paparkan Program Hadapi Bonus Demografi Ke Milenial," n.d., https://news.detik.com/berita/d-4823020.
} 
all can actually $\mathrm{h}$ appen because of the contents of the information technology product, which contains good, moral, educative, humane things as well as things that are not good, immoral, uneducated and inhumane that can plays the both part of its role at the same time. According to that, the main point of education is to see the problems above as a challenge that must be addressed together at the both level :religious-based education and non - religious or secular education.

From the experience in the history of education, especially in formal education ground from elementary to higher educational system in schools and colleges, if there are things that become problems of society which is visible as a result or output of education, then there are at least three issues that are speedily exposed. They are: curriculum, teacher or lecturer and the learning strategies. Although it is obvious that the curriculum is not the only reason, the adjustment of curriculum into the dynamic context of society have to be consider as an important factor. To overcome the negative things as stated above, the curriculum contents must be appropriate and relevant to the basic needs of the community.

Three curriculum contents that need to be considered are: firstly, moral education which contains values that plays role as regulator and guidance of human behaviors. Secondly, strengthening religious education to improve people spirituality and faith in God The Creator. Thirdly, humanities- based education as a method of strengthening and strengthening a sense of solidarity among human beings.

In addition to the curriculum, another factor that is very important to be addressed is: adjustment of learning strategies. If the learning process is defined as a conscious and planned effort carried out in order to create conditions that allow students to learn successfully, then the selection and the use of appropriate learning strategies is something that should not be ignored. The characteristics of millennial students who are creative, productive and communicative- because they are connected to each other through advanced information technology channels- are good opportunities for teachers or lecturers to choose and apply the appropriate strategies in the learning process. The learning strategy that is based on the principle of TRANSFER OF KNOWLEDGE by positioning the teacher/ lecturer as the only source of knowledge has to be avoided because it is not in accordance with the conditions of students who have the very different characteristics than the students from the era before. Teacher or lecturer plays role as facilitator, organizer and mediatorin the learning process by giving a larger portion to student through multi-directional communication so that student creativity can be improved in 
order construct knowledge for their own efforts. Thus, the constructivism learning strategies with cooperative models can be used in the learning process. ${ }^{4}$

These learning models will provide more opportunities to both students with high or low capability in order to share their knowledge. Besides, cooperative learning models will be allow students to learn to respect together students by the spirit of togetherness by always upholding group norms. Related to that, some cooperative learning models that can be used include, (1) STAD (student Team Achievement Diviion (2) TAI (Team Assited Individualization), (3) Four E model (Explore, Explain, Extend and Evaluate), (4) CIRC (Cooperative Integrated Reading and Compositio), (5) Learning Together, (6) Problem Based Instuction models).

\section{CONSLUSION}

Studies of religions view syncretism as a fusion phenomenon of various religious teachings and cults. Syncretism is considered a tendency that is not realized but is often confirmed by the interests of a broader interest. As long as humans are still there and the age continues to develop syncretism will certainly exist. Even though the tendency is often not realized, in practice it is often confirmed as a new teaching and culture. In this situation religious ideas are adjusted according to the religious principles of other religions. One of the syncretic choices is to take a clear line between culture and the gospel. But as a result there has been a development of multiple systems.

Syncretism is debated, especially in the Pentecostal-Charismatic school, must be responded with a cold head. Taking a wise attitude in understanding other religions needs to be taken early. Syncretism is arguably the joint decision-making process in overcoming various problems including those related to phenomena and theology.

In response to the phenomenological problem of Synchronism, the church must be wise. The more so if it is associated with methods and strategies and mission. The church should be open and not easy to be negative about all elements of change that are relevant and do not contain elements that are contradictory to the biblical foundation. But the church cannot accept each teaching as long as it is tested and analyzed carefully, but is more required to be sensitive, positive, selective and creative. Positive selectively and creatively the church can start, use and make use of what is there. And it negates the view that it harms or denies the Christian faith, especially those related to the gospel.

\footnotetext{
${ }^{4}$ Gerson Ratumanan Tanwey, Konstruktivisme Dan Implikasinya Dalam Belajar Dan Pembelajaran (Ambon: FKIP Unpatti, 2002).
} 
With the phrase Let you be rooted in Him and be built on Him, let you increase firmly in the faith that has been taught to you, and let your heart overflow with gratitude (Colossians 2: 7). The Apostle Paul meant that: The Church of God is like a plant seed that is spread to grow and bear fruit in its own place where Christ is already there. Christianity must give independence in a responsible manner to the people in the new environment to understand, pervade, appreciate and express (express) their universal and transcendent faith in Christ according to their personality, culture and environment. This is legitimate and indeed has happened throughout the course of the history of Christianity.

\section{BIBLIOGRAPHY}

Budi, Kurniasih. "Sambut Bonus Demografi, Indonesia Dorong Negara G-20 Kerja Sama," n.d. https://money.kompas.com/read/2019/06/24/205905526/sambutbonus-demografi-indonesia-dorong-negara-g-20-kerja-sama?page=all.

Munir. Pembelajaran Jarak Jauh Berbasis Teknologi Informasi Dan Komunikasi. Bandung: Alfabeta, 2009.

Tanwey, Gerson Ratumanan. Konstruktivisme Dan Implikasinya Dalam Belajar Dan Pembelajaran. Ambon: FKIP Unpatti, 2002.

"HIPMI Paparkan Program Hadapi Bonus Demografi Ke Milenial," n.d. https://news.detik.com/berita/d-4823020. 